\title{
Evaluation of the observance of health protocols and requirements of the environmental and occupational health center against COVID-19 in men's hairdresser salons of Birjand, Iran, in 2020
}

\author{
Mostafa Hosseinzadeh ${ }^{10}$, Abbas Ali Ramazani ${ }^{2}{ }^{2}$, Ali Yousefinia ${ }^{i}{ }^{1}$, Maryam \\ Khorashadizadeh ${ }^{\left(D^{3}\right.}$, Ghaem Barati ${ }^{3}{ }^{3}$, Maryam Khodadadi ${ }^{4} *$
}

\begin{abstract}
Background and Aims: The Coronavirus has become a global pandemic that has affected most countries in the world. Hairdresser salon as a public place can transmit infectious diseases, such as AIDS, hepatitis as well as viral, fungal, and skin diseases that are often due to non-compliance with hygiene principles. This study aimed to investigate the observance of health instructions regarding the prevention and control of Coronavirus disease in men's hairdresser salons in Birjand, Iran, in 2020.

Materials and Methods: In this cross-sectional descriptive study, 145 hairdresser salons in Birjand were selected through the random sampling method. The data collection tool was a checklist that was prepared according to the guidelines of the Ministry of Health and Medical Education. The obtained data were analyzed in SPSS software (version 18) using Mann-Whitney and Kruskal-Wallis tests at a significance level of $\leq 0.05$.
\end{abstract}

Results: The findings showed that the total mean score of the observance of workplace health and hygiene guidelines was $24.28 \pm 2.52$ and the average observance of health instructions in the field of health and personal protection, building hygiene, tool and equipment hygiene, and food hygiene were $13.73 \pm 2.08$, $2.31 \pm 0.68,7.22 \pm 0.64$, and $1.01 \pm 0.11$, respectively. Observance of health instructions was found to have a significant relationship with age and geographical region $(\mathrm{P} \leq 0.05)$.

Conclusion: According to the results, it seems necessary to train hairdressers in terms of observing health instructions. Moreover, men's hairdresser salons should be continuously monitored by health experts.

Keywords: Coronavirus, Hairdressers, Health Instructions

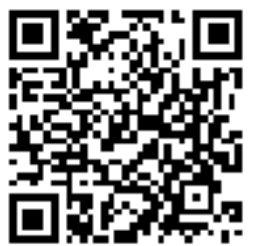

Citation: Hosseinzadeh M, Ramazani AA, Yousefinia A, Khorashadizadeh M, Barati Gh, Khodadadi M. [Evaluation of the observance of health protocols and requirements of the environmental and occupational health center against COVID-19 in men's hairdresser salons of Birjand, Iran, in 2020]. J Birjand Univ Med Sci. 2021; 28(4): 365-374. [Persian]

DOI http://doi.org/10.32592/JBirjandUnivMedSci.2021.28.4.105

Received: April 20, $2021 \quad$ Accepted: October 2, 2021

\footnotetext{
Student Research Committee, Birjand University of Medical Sciences, Birjand, Iran

${ }^{2}$ Social Determinants of Health Research Center, Department of Epidemiology and Biostatistics, Faculty of Health, Birjand

University of Medical Sciences, Birjand, Iran

${ }^{3}$ Department of Environmental Health, Deputy of Health, Birjand University of Medical Sciences, Birjand, Iran

${ }^{4}$ Social Determinants of Health Research Center, Department of Environmental Health Engineering, Faculty of Health, Birjand University of Medical Sciences, Birjand, Iran
}

* Corresponding author: Social Determinants of Health Research Center, Department of Environmental Health Engineering, Faculty of Health, Birjand University of Medical Sciences, Birjand, Iran Tel: +985632381661 Fax: +985631631651

E-mail: maryam.khodadadi@gmail.com 


\title{
بررسى رعايت بروتكلهاى بهداشتى و الزامات مركز سلامت محيط و كار در مبارزه با كوويد - 19 در

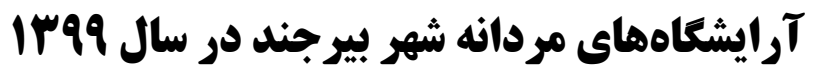

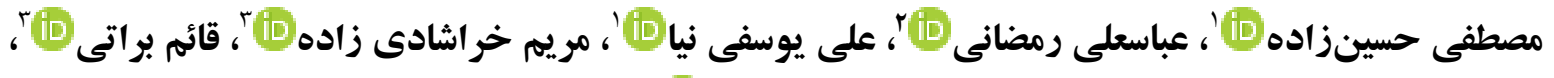 \\ * مريم خدادادى (iD)
}

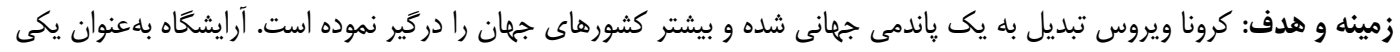

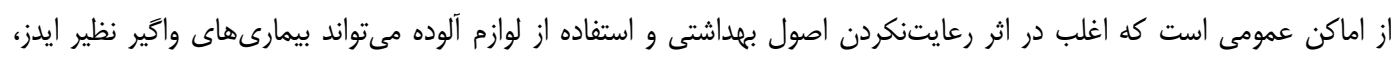

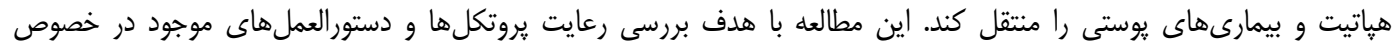

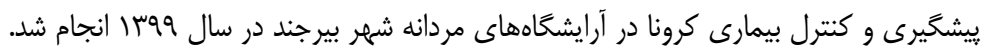

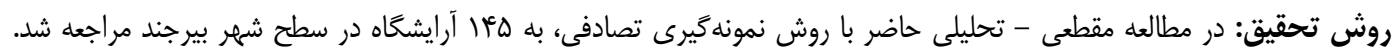

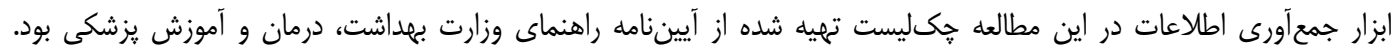

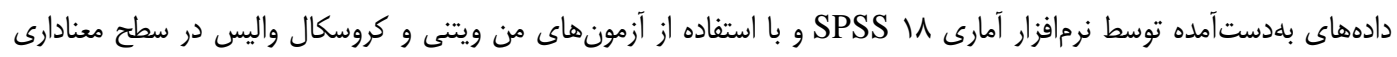

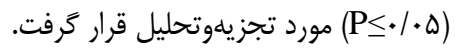

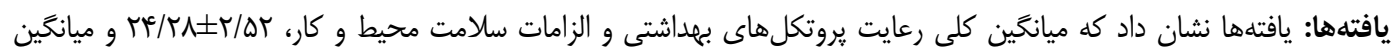

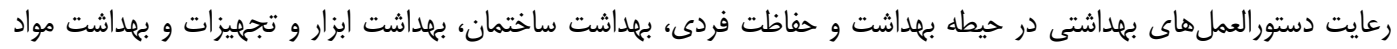

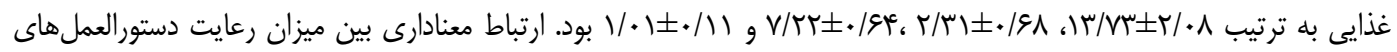

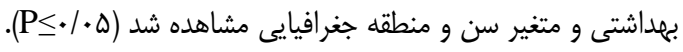

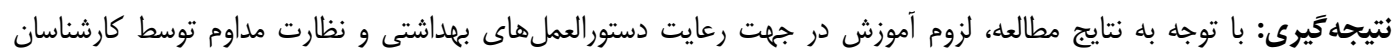

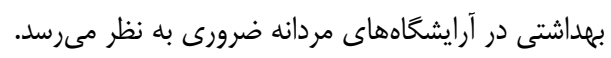
وازههاى كليدى: ويروس كرونا، آرايشكاه، بروتكلهاى بهداشتى ترسي

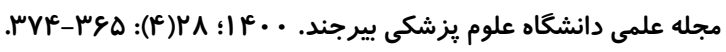

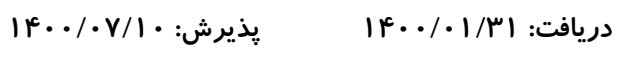

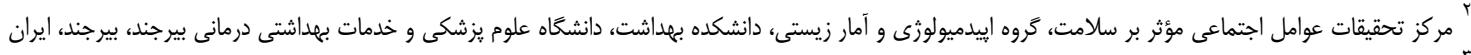

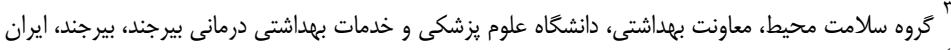

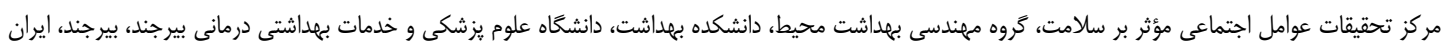


طبق آيين نامه بهداشت محيط به مكانهايى كه متعلّق به عموم

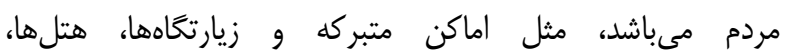
مسافرخانهها، آسايشگاههاى سالمندان، آرايشگاهذا، مدارس و و اماكن مشابه كَفته مىشود، وجود دارد جونكه اين ويروس مى متواند بلهصورت ترشحات در سطوح دو تا سه روز و بلهصورت آئروسل در هوا تا سه ساعت زنده بماند و احتمال انتقال اين ويروس در فاصله

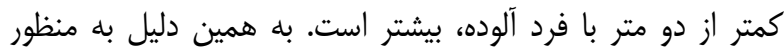
جلوگيرى از شيوع اين ويروس در محيط كار، انجام اقدامات

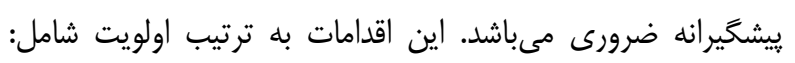
حذف يا جايغزينى عامل آسيبرسان، اقدامات مهندسى، مديريتى و

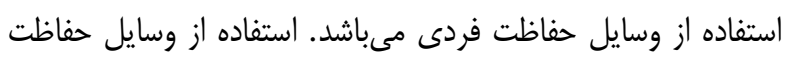
فردى همواره آخرين راه كنترل عوامل زيان آور در محيط كار مارد مىباشد؛ امّا در خصوص ويروس كروناى جديد با توجه به امكان رداه

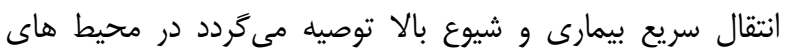
كارى از روشهاى تلفيقى كنترلى يعنى مهندسى، مديريتى و وسايل

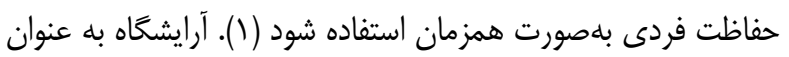
يكى از اماكن عمومى مىتواند بيمارىهاى مختلفى مانند ايدز،

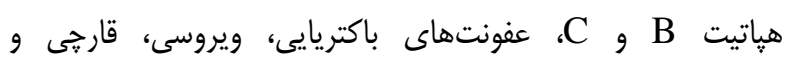

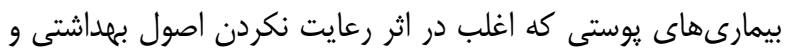
استفاده از لوازم آلوده إيجاد مىشودرا منتقل كند (ه). خطر ابتلا به بيمارى كوويد-19 در آرايشًاهها به دليل اينكه

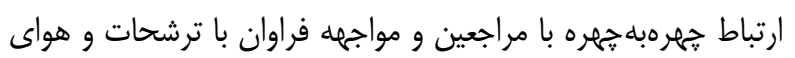
بازدم بيماران و همجنين استفاده از وسايل و ابزار كار آلوده مانند حوله، برس و تيغ و غيره منجر به كسترش اين بيمارى شود، وجود

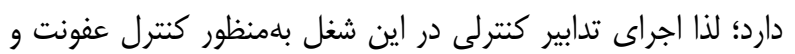
جلو ميرى از انتقال فردى بسيار حائز اهميت است (و, ()). لذا با توجه

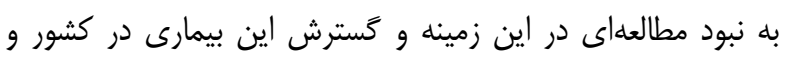

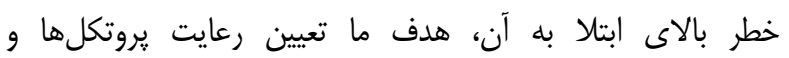
دستور العمل هاى موجود در خصوص بيشگيرى و كنترل بيمارى كرونا

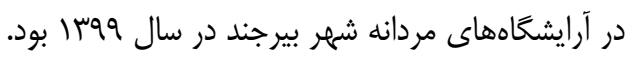

\section{مقلdمه}

امروزه كرونا ويروس تبديل به يك ياندمى جهانى شده و تقريباً همه كشورهاى جهان را دركير نموده است. اين ويروس كه كرونا

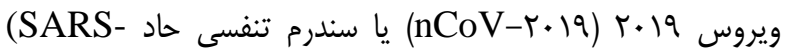
ناميده مىشود، تهديدى بزرى براى سلامت جامعه

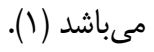

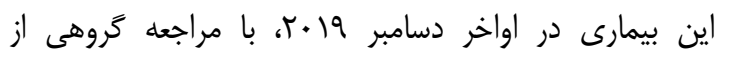

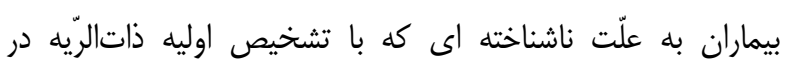

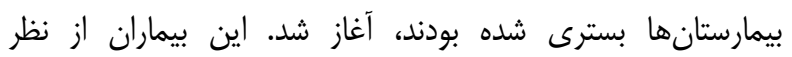

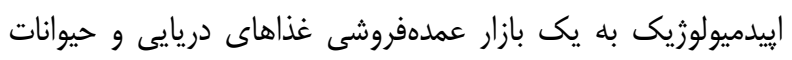

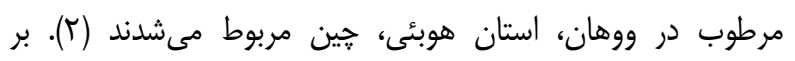

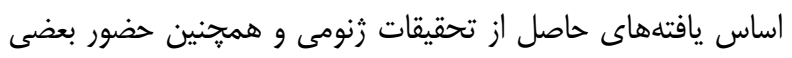

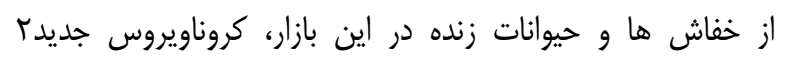

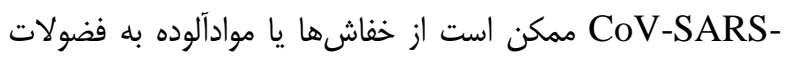
خفاشها در اين بازار يا نواحى اطراف آن منشأ كرفته باشد (َّ).

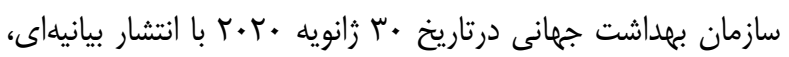
شيوع كروناويروس جديد را ششمين عامل وضعيت اضطرارى بهداشت عمومى در سرتاسر جهان اعلام نمود كه تهديدى نه فقط رئط

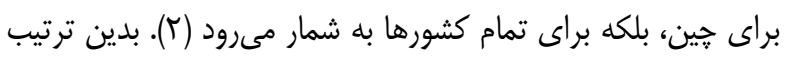

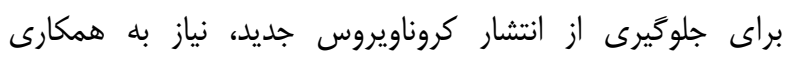

كار كنان بهداشتى، دولتها و عموم مردم با يكديخر مىباشد (َّ).

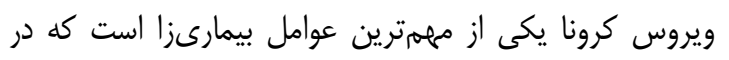

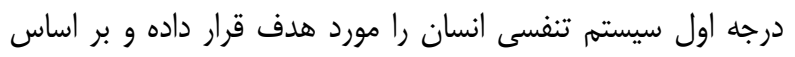

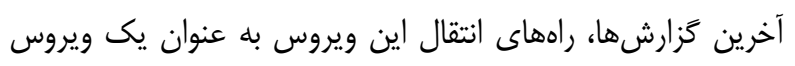

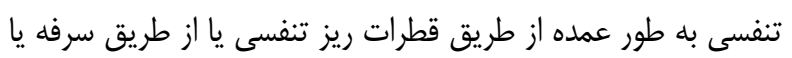

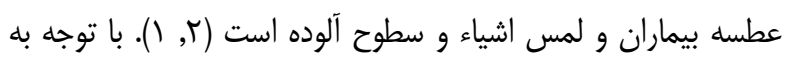

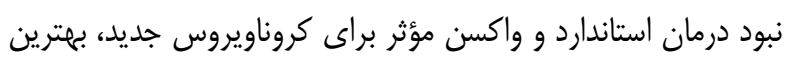

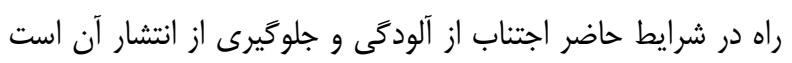

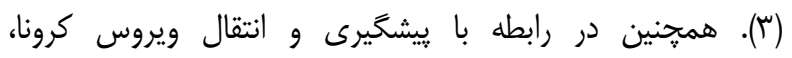

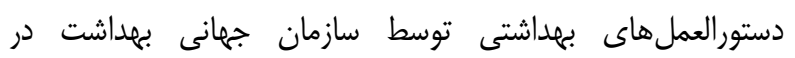
خصوص مشاغل و لزوم رعايت موازين بهداشتى در محيط هاى كار

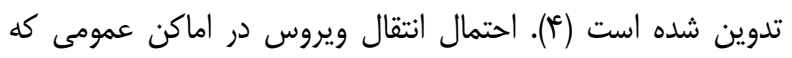


و كروسكالواليس جهت تحليل نتايج استفاده كرديد و سطح معنىدار

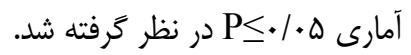

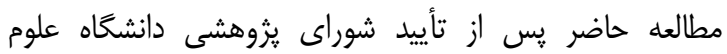

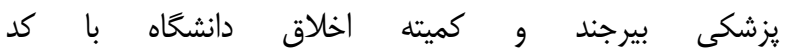
IR.BUMS.REC.1399.401

\section{يافته ها}

در اين يثوهش هأ| آرايشكاه مردانه شهر بيرجند مورد بررسى

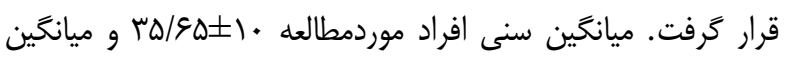

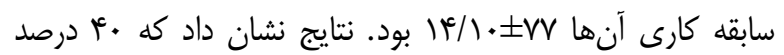
افراد مورد مطالعه، سن بين بيست تا سىسال، WV درصد افراد متأهل

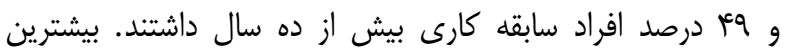

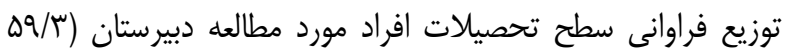

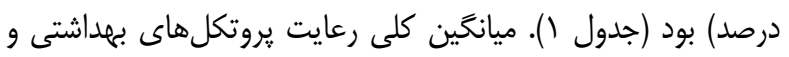

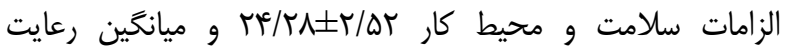
يروتكلهاى بهداشتى در حيطه بهداشت و حفاظت فردى 1•//

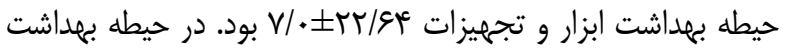

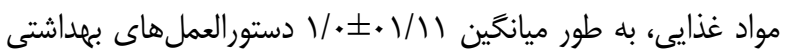
رعايت شد (نمودار()). نتايج نشان داد كه بين ميزان رعاين رعايت

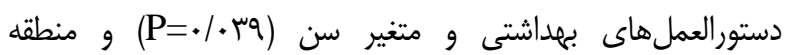

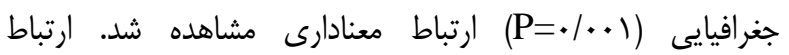

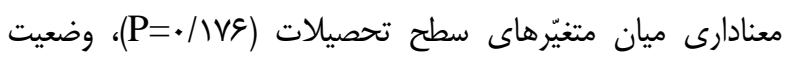

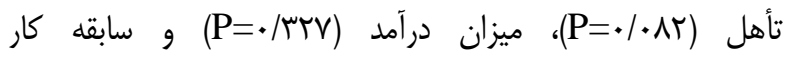
(P=•/I بV) (جدول ()). در حيطه بهداشت و حفاظت فردى، بيشترين توزيع فراوانى رعايت يروتكلهاى بهداشتى مربوط به رعايت بهداشت دست و استفاده از ماسك و كمترين توزيع فراوانى مربوط به استفاده

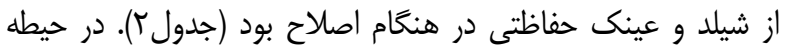
بهداشت ساختمان، استفاده از جعبه ايمن براى جمع آورى يسماندهاى تيز و برنده بيشترين توزيع فراوانى و تخليه و كَندزدايى روزانه سطلهاى پِسماند كمترين توزيع فراوانى را داشتند (جدولـــالف).

\section{روش تحقيق}

در اين مطالعه توصيفى_تحليلى، ابتدا شهر بيرجند به ه منطقه جغرافيايى شمال، جنوب، شرق، غرب و مركز تقسيم شد و سبس از

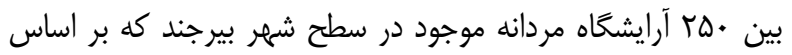
اطلاعات به دست آمده از اتحاديه صنف آرايشكَران، فعاليت رسمى

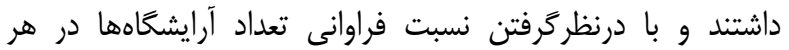
منطقه با روش نمونهگيرى تصادفى ساده، هأ| آرايشخاه بهعنوان

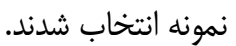
حجم نمونه در اين مطالعه با استفاده از فرمول زير و با توجه به

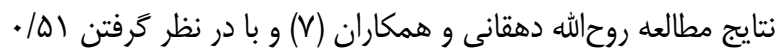

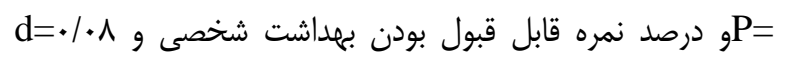

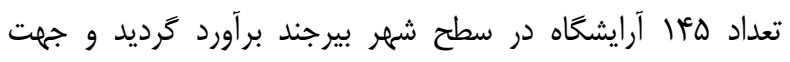

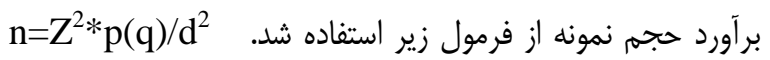

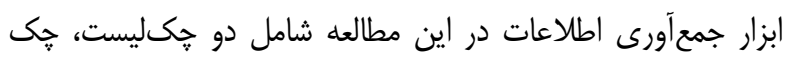

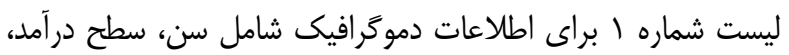
سابقه كار، وضعيت تأهل، سطح تحصيلات و منطقه جغرافيايى و جى ليست شماره r تهيه شده از آيين نامه راهنماى كام دوم مبارزه

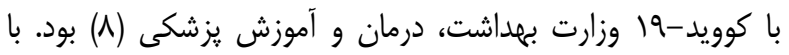

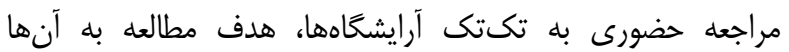
توضيح داده شد و پِ از كسب رضايت آنها به صاحبان آرايشگاهها

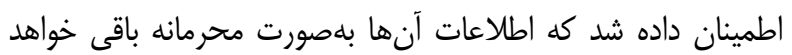

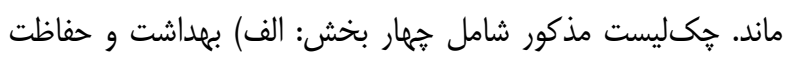
فردى (1) سؤال)، ب) بهداشت ساختمان (أ سؤال)، ج) بهداشت

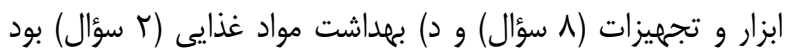

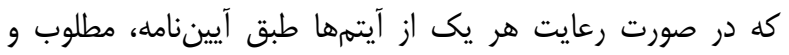
نمره ا و در صورت عدم رعايت، نامطلوب و نمره صفر در نظر خرفته شد و جمع نمرات در هر كدام از بخشها در صورت مطلوب بودن همه موارد و مطابقت با آيينامه به ترتيب بخش الف (1) نمره)،

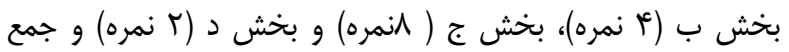

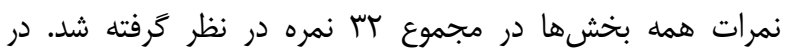

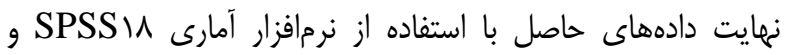
Excel 
(جدولץ_ب). در حيطه بهداشت مواد غذايى بيشترين رعايت مربوط

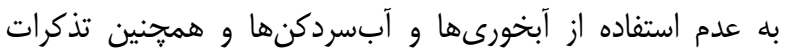
لازم مبنىبر ممنوع بودن مصرف مواد خوراكى و آشاميدنى به به بهنين مشتريان بود (جدول مـ ج).
در حيطه بهداشت ابزار و تجهيزات، بيشترين توزيع فراوانى مربوط به

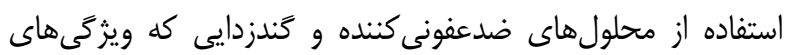
لازم را داشتند و كمترين توزيع فراوانى مربوط به استفاده از دستخاه

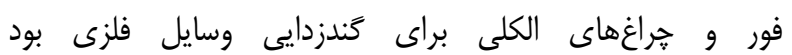

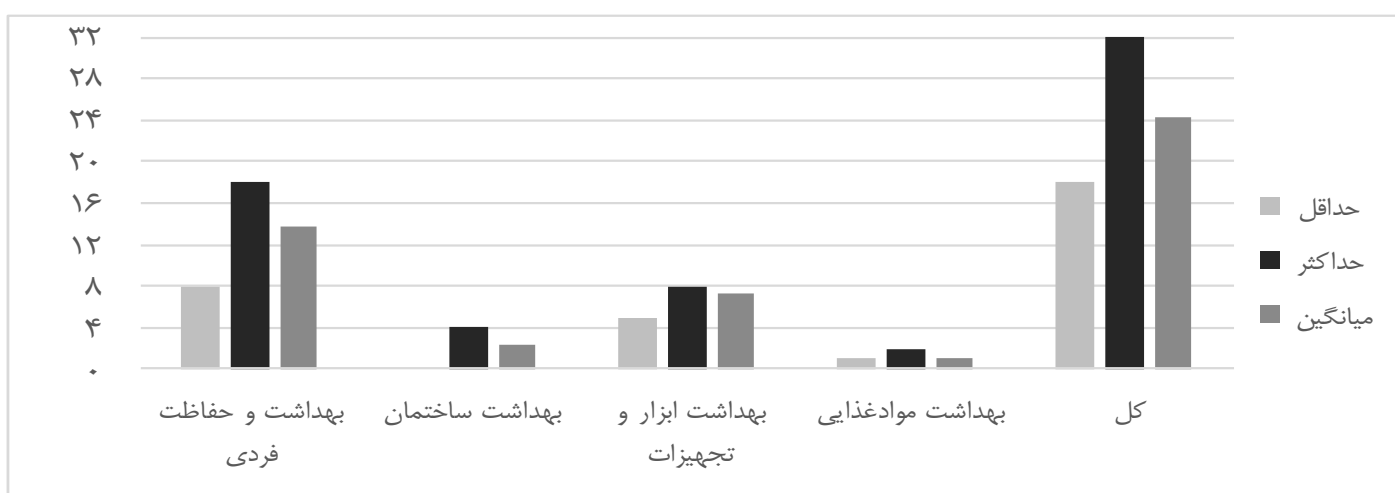

نمودار ا - حداقل، حداكثر و ميانكَين رعايت يروتكلهاى بهداشتى و الزامات سلامت محيط وكار توسط افراد موردمطالعه

جدول ا - مقايسه ميانكَين رعايت يروتكلهاى بهداشتى و الزامات سلامت محيط وكار برحسب متغيرهاى دموَّر افيكى در افر اد موردمطالعه

\begin{tabular}{|c|c|c|c|c|c|}
\hline $\mathrm{P}$ value & ميانگين & درصد & تعداد & محدوده & متغير \\
\hline \multirow{3}{*}{$=.1 .4 q$} & $r \mu / v \Delta$ & f. & $\Delta \wedge$ & r.r تا •r سال & \multirow{3}{*}{ سن سن } \\
\hline & TE/Tt & 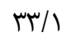 & is & •r تا •• سال & \\
\hline & $r \Delta / I r$ & $r \varepsilon / q$ & rq & بيش از •• سال & \\
\hline \multirow{3}{*}{.$/ 1 V 8$} & $r \Delta / \Delta \Delta$ & $r \varepsilon / r$ & щی & ابتدايى و راهنمايى & \multirow{3}{*}{ سطح تحصيلات } \\
\hline & $r m / q r$ & $\Delta q / \pi$ & $\wedge \varepsilon$ & دبيرستان & \\
\hline & $r 4 / 19$ & $14 / 0$ & rI & دانشخاهى & \\
\hline \multirow{2}{*}{. $/ 14$} & $r \mu / \Delta V$ & $r r / \Lambda$ & سז & مجرد & \multirow{2}{*}{ وضعيت تاهل } \\
\hline & $r F / \& q$ & $V V / r$ & 114 & متاهل & \\
\hline \multirow{3}{*}{.$/ 19 V$} & $r M / v a$ & $r r / \Lambda$ & سז & كمتر از ه سال & \multirow{3}{*}{ سابقه كار } \\
\hline & $r \mu / q \Delta$ & $r N / r$ & il & ه تا •• سال & \\
\hline & $r+R$ & 19 & n & بيش از • ا سال & \\
\hline \multirow{3}{*}{. ITrV } & $r F / F$ & $f 1 / 9$ & iv & كمتر از ه// ميليون تومان & \multirow{3}{*}{ ميزان درآمد } \\
\hline & rM/99 & $r T / 1$ & ש & ه/ ا تا ץ ميليون تومان & \\
\hline & $r F / .9$ & re & rq & بيش از r ميليون تومان & \\
\hline \multirow{5}{*}{$* * 1 .+1$} & $r \Delta / r$. & $r \cdot / V$ & r. & مركز & \multirow{5}{*}{ منطقه } \\
\hline & $r M / \Lambda F$ & $r \cdot / V$ & $r \cdot$ & شرق & \\
\hline & $r M / M$ & $I V / r$ & ra & غرب & \\
\hline & rT/Ar & $r \cdot / V$ & r. & شمال & \\
\hline & $r \omega / Q$. & $r \cdot / r$ & r. & جنوب & \\
\hline
\end{tabular}


جدول r- توزيع فر اوانى رعايت يروتكلهاى بهداشتى و الزامات سلامت محيط وكار افر اد موردمطالعه برحسب بهداشت و حفاظت فردى

\begin{tabular}{|c|c|c|c|}
\hline درصد & تعداد & 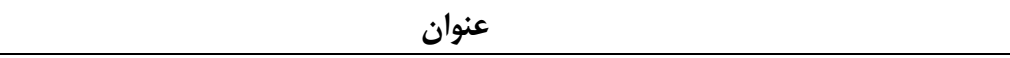 & رديف \\
\hline $9 \varepsilon / 9$ & 14. & آيا آرايشخر در هنگام اصلاح از ماسك استفاده مى كند؟ & 1 \\
\hline rq & et & آيا آرايشگر در هنگًام اصلاح از شيلد و عينك حفاظتى استفاده مى كند؟ & r \\
\hline $9 \cdot / 4$ & II & آيا فاصله حداقل يك متر بين افراد در آرايشكاه رعايت مىشود؟ & r \\
\hline $99 / 9$ & १७ & آيا آرايشكر از رويوش تميز و لباس آستيندار استفاده مى كند؟ & c \\
\hline MI/V & is & آيا آرايشگر در هنگام اصلاح از دستكش استفاده مى كند؟ & Q \\
\hline sr/1 & q. & آيا يوستر راهنماى نحوه صحيح شستشوى دستها در معرض ديد مراجعه كنندكان نصب شده است؟ & 8 \\
\hline$+4 \% / 1$ & st & آيا لباس كار آرايشخر روزانه شستشو و كندزدايى مىشود؟ & $\checkmark$ \\
\hline$r / \Lambda$ & pq & آيا يوسترهاى هشداردهنده در مورد انتقال بيمارى كرونا نصب شده است؟ & $\Lambda$ \\
\hline$\Lambda V / \&$ & ITV & آيا توصيه و در اختيار قراردادن ماسك ساده به مشتريان در صورت فراموش نمودن ماسك انجام مىشود؟ & 9 \\
\hline $9 \vee / 4$ & $\mid 14$ & آيا از يذيرش مشتريان با علايم تب، سرفه، كلودرد و تنكى تنفسى جلوكيرى مىشود؟ & 1. \\
\hline$V \pi / \Lambda$ & $1 \cdot V$ & آيا نوبتدهى بلهورت تلفنى و يا ايتترنتى انجام مى شود؟ & 11 \\
\hline १४/१ & let & آيا بهداشت دست شامل شستوشوى دستها با آب و صابون و يا محلولهاى ضدعفونى انجام مىشود؟ & it \\
\hline $9 / / 8$ & Ifr & آيا دريافت وجه از طريق كارتخوان انجام مىشود؟ & Ir \\
\hline $9 Y / T^{\circ}$ & ImF & آيا كد رهكَيرى از سامانه salamat.gov.ir دريافت شده است؟ & $1 f$ \\
\hline $9 \vee / 4$ & $|4|$ & آيا همأ كاركنان مشمول، كارت بهداشت معتبر دارند؟ & 10 \\
\hline $9 \vee / 9$ & let & آيا هر يك از مشتريان وسايل شخصى مخصوص اصلاح به همراه خود مىآوردند؟ & 19 \\
\hline $\mathrm{V} / \mathrm{r}$ & 110 & آيا از وسايل مشترك براى آرايش و ييرايش استفاده مىشود؟ & iv \\
\hline $9 \& / 8$ & 11. & در صورت استفاده از وسايل مشترك، آيا گندزدايى بلصورت صحيح انجام مى شود؟ & 11 \\
\hline
\end{tabular}

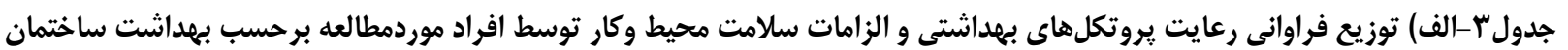

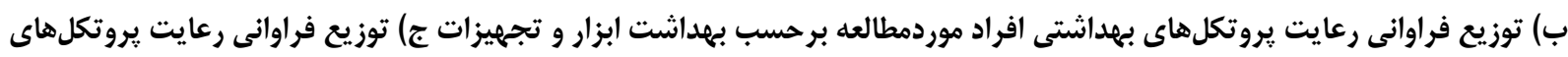

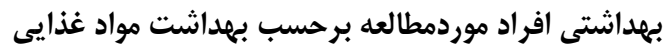

(الف)

\begin{tabular}{|c|c|c|c|}
\hline درصد & تعداد & عنوان & رديف \\
\hline$r y / \Lambda$ & $9 \Delta$ & آيا تهويه مناسب، بلهورى كه هواى تازه هميشه در جريان باشد وجود دارد؟ & 1 \\
\hline$\Lambda 9 / \mathrm{V}$ & Ir. & آيا كليه يسماندهاى تيز و برنده در جعبه ايمن (safety box) جمعآورى مى كردد ؟ & $r$ \\
\hline $11 / 4$ & 111 & آيا سطل زباله دربدار يدالى براى يسماندهاى توليدى دارد؟ & r \\
\hline $10 / r$ & tr & آيا تخليه روزانه سطل هاى يسماند و كَندزدايى سطلها انجام مىشود؟ & f \\
\hline \multicolumn{4}{|c|}{ (ب) } \\
\hline درصد & تعداد & 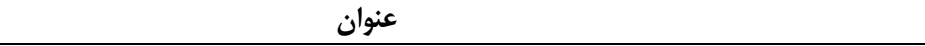 & رديف \\
\hline $9 \Delta / r$ & ira & آيا تجهيزاتى مانند حوله، سربند، ييشبند و... يكبار مصرف استفاده مى شود؟ & 1 \\
\hline $99 / \%$ & life & آيا صابون مايع و دستمال كاغذى در توالتها و سرويس هاى بهداشتى وجود دارد؟ & $r$ \\
\hline $9 \vee / 9$ & let & آيا دستخيره در ورودى و ساير سطوحى كه در معرض تماس مشترك هست بطور مرتب كندزدايى مىشود؟ & r \\
\hline $9 \vee / 9$ & let & آيا كَندزدايى سطوح و تجهيزات با استفاده از مواد كندزداى مناسب بعد از هر اصلاح انجام مىشود؟ & f \\
\hline $9 \vee / r$ & $\mid 41$ & آيا در آرايشكاه محلول هاى ضدعفونى دست براى شاغلين و مراجعه كندكًان موجود است؟ & Q \\
\hline ११/\% & life & آيا بعد از انجام هركّونه امور آرايشى كليه وسايل حفاظتى استفاده شده به نحو صحيح دفع مىشود؟ & s \\
\hline$r \Delta / 9$ & or & آيا از دستخاه فور و يا هراغهاى الكلى براى گندزدايى وسايل فلزى استفاده مىشود؟ & $\checkmark$ \\
\hline $1 \ldots$ & $1 F \Delta$ & آيا محلول هاى ضدعفونى كننده و كَندزداى مورداستفاده داراى ويزُكى هاى لازم مىباشند؟ & $\Lambda$ \\
\hline \multicolumn{4}{|c|}{ (ج) } \\
\hline درصد & تعداد & 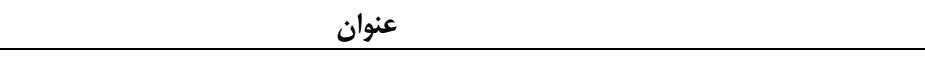 & رديف \\
\hline $9 \mathrm{~N} / \mathrm{9}$ & IfT & آيا از آبخورى ها و آبسردكنها در آرايشكاهها استفاده نمىشود؟ & 1 \\
\hline $1 .$. & 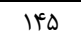 & آيا تذكرات لازم مبنىبر ممنوع بودن مصرف مواد خوراكى و آشاميدنى به مشتريان داده شده است؟ & r \\
\hline
\end{tabular}


بوده و 19/Vدرصد از جعبه ايمن' بلمنظور جمعآورى بسماندهاى تيز

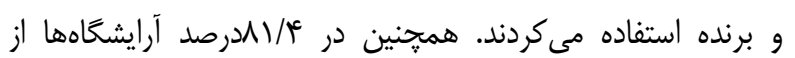
سطل زباله دربدار استفاده مىشد كه به نظر مىرسد يكى از دلايل

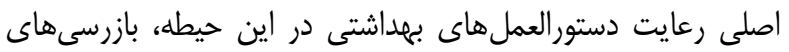
منظمه و روتين كارشناسان بهداشت محيط و ملزم نمودن متصديان اين صنف در جهت رعايت اصول مد نظر در اين زمينه مىباشد. در

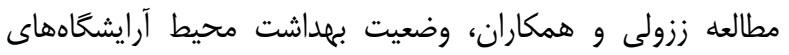
بخش بهنمير، شهر بابلسر واقع در استان مازندران مورد مطالعه قرار ورار

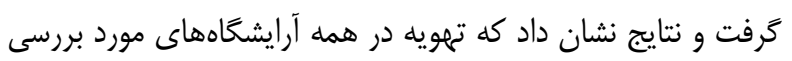

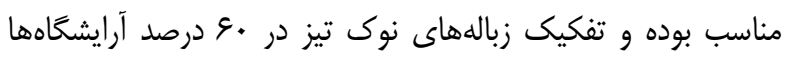

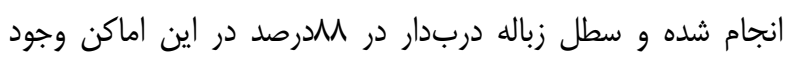

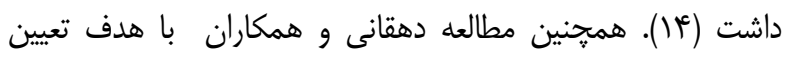
وضعيت بهداشت محيطى سالنهاى زيبايى كاشان انجام شد و نتايج

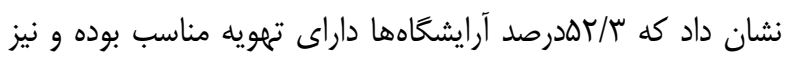

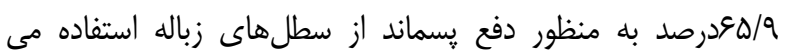
كردند (V)

نتايج حاكى از رعايت •جدرصدى دستورالعملهاى بهداشتى در حيطه بهداشت ابزار و تجهيزات مورداستفاده در آرايشگاهها مى آناشد.

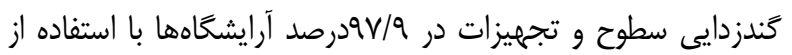

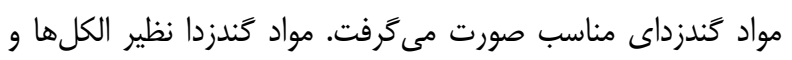

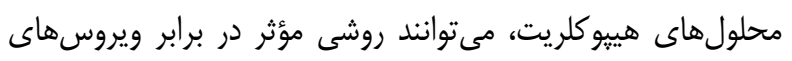
SARS-CoV داده است كه ويروس COVID-19 مىتواند تا 9 روز در سطح

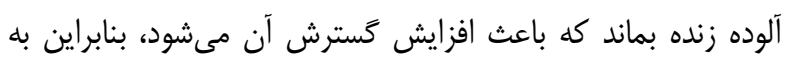

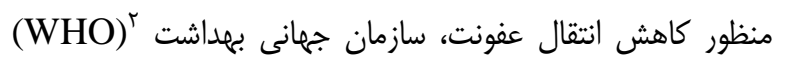

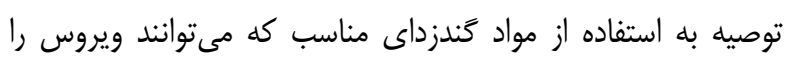
غيرفعال و از بين ببرند، كرده است (ه)). در هودرصد آرايشگاهها تجهيزاتى مانند حوله، سربند، ييشبند و... يكبار مصرف در صورت برد

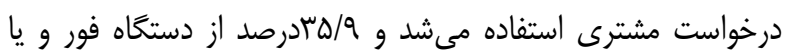
جراغ هاى الكلى براى كَندزدايى وسايل فلزى استفاده مى كردند. در مطالعه صادقى و همكاران، وضعيت كنترل عفونت و كَندزداهاى

\footnotetext{
${ }^{1}$ Safety box

${ }^{2}$ World Health Organization
}

مطالعه حاضر با هدف تعيين رعايت يروتكلهاى بهداشتى و

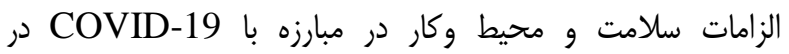

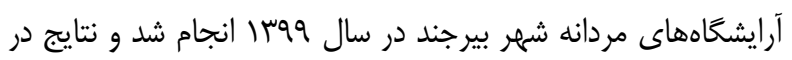
مورد عملكرد متصديان آرايشگاهها حاكى از عملكرد خوب در رعائ درايت

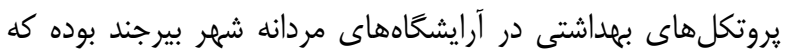

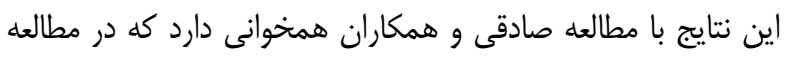

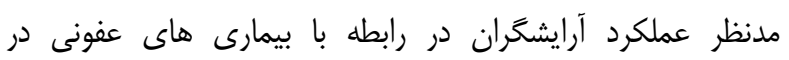

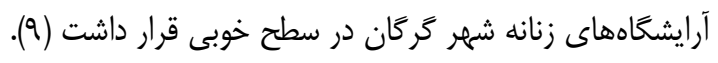
رعايت بهداشت فردى براى كنترل و ييشخيرى از بيمارى

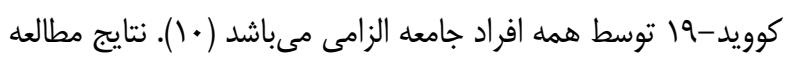
حاضر نشان مىدهد كه دVV دمد دستور العمل هاى بهداشتى در حيطه بهداشت و حفاظت فردى توسط آرايشگران مرد سطح شهر بيرجند

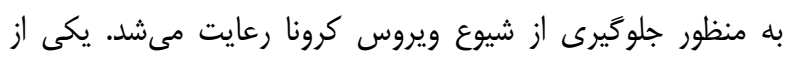

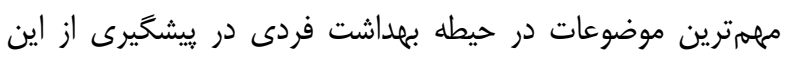

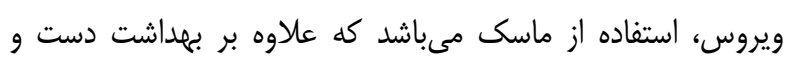

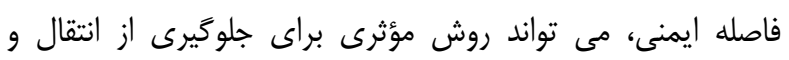

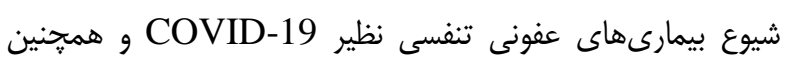
كاهش نقش افراد بدون علامت و يا علائم ضعيف به - COVID

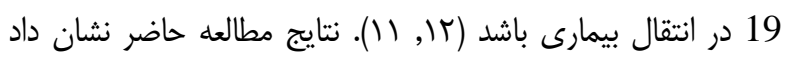
كه \&/ع9درصد آرايشگران در هنگام اصلاح از ماسك استفاده

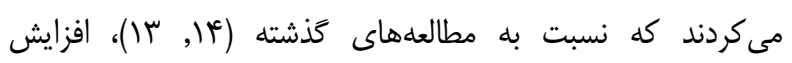
جشمخيرى داشته است كه مهمترين دليل آن بالابردن سطح حساسيت در نتيجه آموزش مسائل بهداشت محيطى در بيشخيرى از كرونا توسط سازمانهاى دستاندركار بوده است. طبق نتايج مطالعه دئه Vincent Chi-ChungCheng سطح جامعه مىتواند ميزان انتشار بزاق آلوده و قطرات تنفسى را از

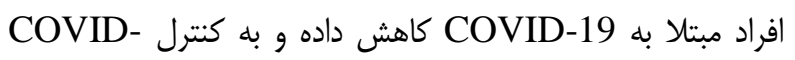
19 كمك كند (1) نتايج نشان مىدهد كه رعايت دستورالعملهاى بهداشتى در

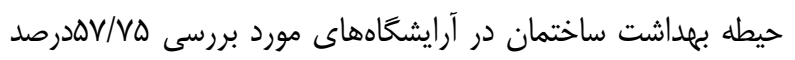

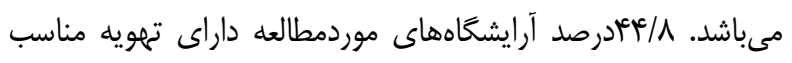




\section{نتيجه تيرى}

بر اساس نتايج مطالعه ميزان رعايت يروتكلهاى بهداشتى و الزامات سلامت محيط و كار در آرايشگاههاى مردانه سطح شهر بيرجند و همجنين رعايت مسائل بهداشت فردى و كَندزدايى وسايل

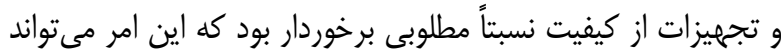
به عنوان يك اقدام ييشگيرانه به منظور جلوَّيرى از شيوع ويروس كرونا در محيط هاى كار ضرورى باشد؛ امّا با توجه به اينكه بيمارى

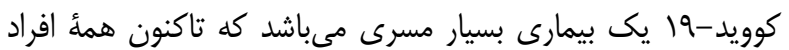

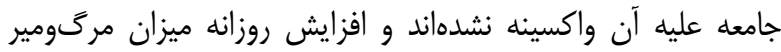
ناشى از اين بيمارى، رعايت كامل بروتكلهاى بهداشتى و الزامات سلامت و محيط وكار در اماكن عمومى و از جمله آرايشگاهها

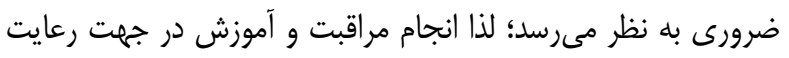
دستورالعملهاى بهداشتى در اين اماكن بلطورجدى بايد موردتوجه بازرسان مراكز بهداشتى و درمانى قراركيرد.

\section{تقدير و تشكّر}

اين مطالعه، با حمايت مالى معاونت تحقيقات و فناورى دانشكاه علوم يزشكى بيرجند با كد طرح ^سهه انجام شده است. نويسندكان

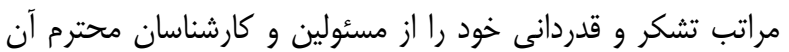
معاونت، دانشكده بهداشت و همه كسانى كه در اجراى اين تحقيق همكارى نمودند، اعلام مىنمايند.

\section{تضاد منافع}

نويسندكان مقاله اعلام مى دارند كه هيج كونه تضاد منافعى در

$$
\text { يزوهش حاضر وجود ندارد. }
$$

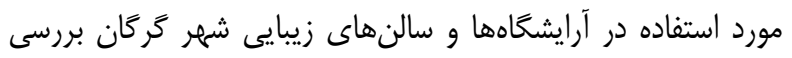

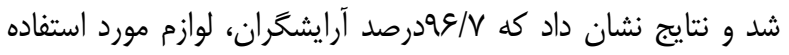

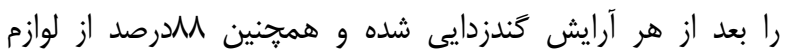
يكبارمصرف استفاده مى كردند (9). در مطالعه Ayano Wakjira عملكرد آرايشگران و كاركنان سالن هاى زيبايى در رابطه با شيوع ويروس 'HIV در اتيويى، كَندزدايى محيط كار و تجهيزات مورد استفاده به صورت روزانه و

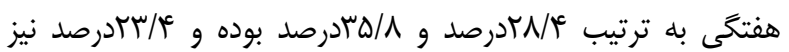

براى كَندزدايى تجهيزات از خراغ الكلى استفاده مى كردند (عاب).

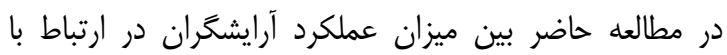
رعايت دستورالعملهاى بهداشتى و متغير سن ارتباط آمارى معنادارى

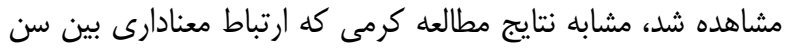

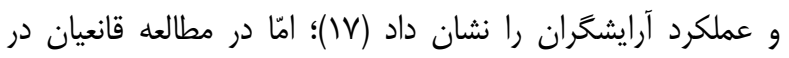

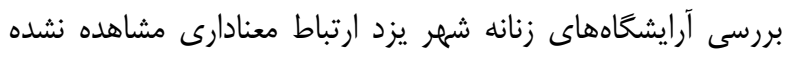

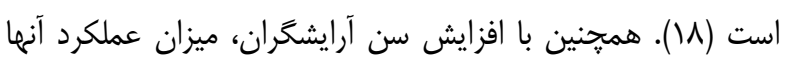

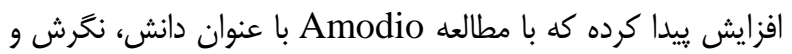

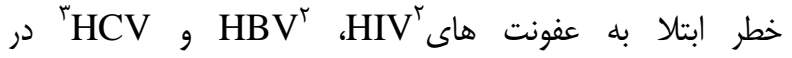

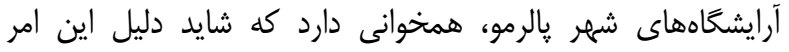

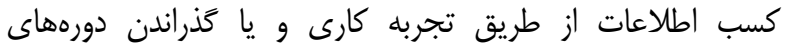

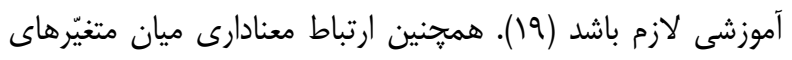

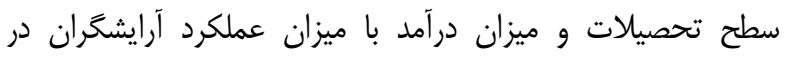

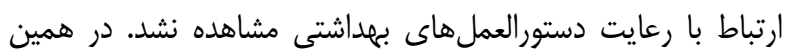

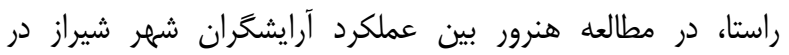

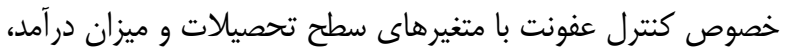
ارتباط معنادارى مشاهده نشد (·r)؛ امّا در مطالعه صادقى و همكاران (9) رابطه معنادارى ميان متغيرهاى سطح تحصيلات و ميزان درآ مد مدان

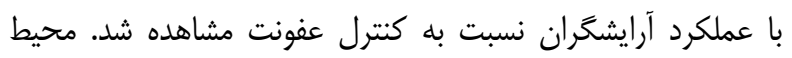

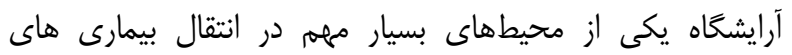

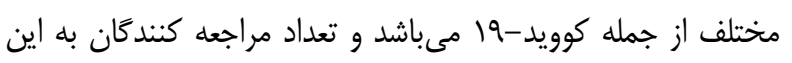

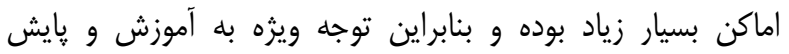

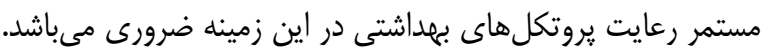

\footnotetext{
${ }^{1}$ Human Immunodeficiency Virus

${ }^{2}$ Hepatitis B Virus

${ }^{3}$ Hepatitis C Virus
} 


\section{منابع:}

1- Rafeemanesh E, Ahmadi F, Movahhed T, Abdollahi O. A Review on Recent Guidelines and Articles about Prevention of Covid-19 Infection in Dental Settings.J Mashhad Dent Sch. 2020; 44(3): 299-307. [Persian]. DOI: 10.22038/JMDS.2020.48058.1907

2- Rothan HA, Byrareddy SN. The epidemiology and pathogenesis of coronavirus disease (COVID-19) outbreak.. J Autoimmun. 2020; 102433. DOI: 10.1016/j.jaut.2020.102433

3- Tavakoli A, Vahdat K, Keshavarz M. Novel Coronavirus Disease 2019 (COVID-19): An Emerging Infectious Disease in the 21st Century. Iran South Med J. 2020; 22 (6): 432-450. [Persian]. DOI: 10.29252/ismj.22.6.432

4- Rafeemanesh E, Rahimpour F, Memarzadeh M. Approaches for Covid-19 infection control in the workplaces. Occup Med. 2019; 11(4). [Persian]. DOI: 10.18502/tkj.v11i4.3653

5- Sadeghi M, Charkazi A, Behnampour N, Zafarzadeh A, Garezgar S, Davoudinia S, et al. Evaluation of infection control and disinfection used in barbershops and beauty salons in Gorgan. Health Environ. 2015; 7(4): 427-36. [Persian]. Link

6- Doshmangir L, Mahbub Ahari A, Qolipour K, Azami-Aghdash S, Kalankesh L, Doshmangir P, et al . East Asia's Strategies for Effective Response to COVID-19: Lessons Learned for Iran. Manage Strat Health Syst. 2020; 4(4): 370-373. [Persian]. DOI: 10.18502/mshsj.v4i4.2542

7- Dehghani R, Mesgari L, Fathi Moghadam M, Rezaian F, Nasudian F, Sudayfian E, et al. Studying the environmental health status of beauty salons of Kashan. Int J Epidemiol Res. 2017; 4(1): 24-30. Link

8- Ministry of Health and Medical Education of the Islamic Republic of Iran. The guideline of the second step in the fight against Covid-19 social distance and health requirements of environment and work in the barbershop. 2020; [cited 2020 April]. Available at: http://eoh.behdashtcdn.ir/159.pdf. Accessed 2021 May.

9- Sadeghi M, Charkazi A, Zafarzadeh A, Borgheie P, Garezgar S, Davoudinia S. Assessing the Adequacy of Knowledge, Attitude and Practice of of the Female Hairdressers Working in the Gorgan Beauty Salons Towrads Infectious Diseases. community health j. 2016; 10(3): 36-44. [Persian]. Link

10- Zorriehzahra MJ, Dadar M, Ziarati M, Seidgar M, Hassantabar F, Ghasemi M, et al. A Perspective on the Origin of COVID-19 and Its Epidemic Situation in Iran and the World. J Mar Med. 2020; 2(1): 41-52. [Persian]. DOI: $10.30491 / 2.1 .2$

11- Cheng VC-C, Wong S-C, Chuang VW-M, So SY-C, Chen JH-K, Sridhar S, et al. The role of community-wide wearing of face mask for control of coronavirus disease 2019 (COVID-19) epidemic due to SARS-CoV-2. J Infect. 2020; 81(1): 107-14. DOI: 10.1016/j.jinf.2020.04.024

12- Esposito S, Principi N. To mask or not to mask children to overcome COVID-19. Eur J Pediatr. 2020; 179(8): 126770. DOI: 10.1007/s00431-020-03674-9

13- Moradi B, Barakat S. Hygienic performance evaluation and effect of training in order to confronting with the Covid-19 virus in the metal industries staff. Iran Occup Health J. 2020; 17(1): 1-12. [Persian]. Link

14- Zuzuli Mohammad Ali, Yousefi Maryam, Nahid. Z. Survey of environmental health status of hairdressers in Bahnamir section of Babolsar city in 2014. Graduate Students Conference; Mashhad University of Medical Sciences. 2014. Mashhad, Iran.[Persian]. Link

15- Al-Sayah MH. Chemical disinfectants of COVID-19: an overview. Journal of water and health. J Water Health. 2020; 18(5): 843-8. DOI: 10.2166/wh.2020.108

16- Ayano Wakjira B. Assessment on Knowledge, Attitude and Practice with Regard to the Transmission and Prevention of HIV/AIDS among Barbers and Beauty Salon Workers in Hossana Town, South Ethiopia. J Clin Diagnostic Res. 2017; 5(1): 2-8. DOI: 10.4172/2376-0311.1000136

17- Karami A, Miandari A, Shoghli A, koli Farhood G. Assess the knowledge and attitude of barbers toward HIV/AIDS infection. Biosci Biotechnol Res Asia. 2015; 12(3): 2279-2286. DOI: 10.13005/bbra/1901 
18- Ghaneian MT, Mehrparvar AH, Jasemizad T, Mansuri F, Selselehvaziri H, Zare F. The Survey Of Knowledge, Attitude And Practice Of Female Hairdressers In Yazd About Diseases Related To Hairdressing Profession In 1391. Occup Med. 2014; 6(2): 54-64. [Persian]. Link

19- Amodio E, Di Benedetto MA, Gennaro L, Maida CM, Romano N. Knowledge, attitudes and risk of HIV, HBV and HCV infections in hairdressers of Palermo city (South Italy). European journal of public health. Eur J Public Health. 2010; 20(4): 433-7. DOI: 10.1093/eurpub/ckp178

20- Honarvar B. Asurvey to the infection control in beauty salons in Shiraz. Iran Occup Health J. 2009; 6(1): 61-7. [Persian]. Link 